\title{
The Foraging Perspective in Criminology: A Review of Research Literature
}

Christophe Vandeviver $^{1,2}$, Elias Neirynck ${ }^{1,2} \&$ Wim Bernasco $^{3,4}$

${ }^{1}$ Department of Criminology, Criminal Law and Social Law, Ghent University, Belgium.

${ }^{2}$ Research Foundation-Flanders (FWO), Brussels, Belgium.

${ }^{3}$ Netherlands Institute for the Study of Crime and Law Enforcement (NSCR), Amsterdam, The Netherlands.

${ }^{4}$ Vrije Universiteit Amsterdam, Spatial Economics, Amsterdam, The Netherlands.

Author for correspondence: Christophe Vandeviver

Email: Christophe.Vandeviver@UGent.be

Declaration of interest: None. 


\section{The Foraging Perspective in Criminology: A Critical Review of Research Literature Abstract}

In order to explain how crimes are carried out, and why at a particular place and time and against a specific target, crime researchers increasingly engage with theory from behavioural ecology, in particular Optimal Foraging Theory (OFT). However, an overview of their main findings does not exist . Given the growing focus on OFT as a behavioural framework for structuring crime research, in this article we review the extant OFT-inspired crime research. Search in Google Scholar and Web of Science yielded 32 crime studies, which were grouped into four categories according to the focal decision being modelled. Empirical results largely support predictions made by OFT. There remains much potential for future crime research, however, in particular regarding the theoretical foundation of OFT in criminology, and through the application of contemporary extensions to OFT using specific tools developed for the study of animal foraging decisions.

Keywords: Offender-forager, Environmental criminology, Behavioural Ecology, Systematic Search and Review, Optimal Foraging Theory

\section{INTRODUCTION}

Environmental criminology concerns itself with explaining where and when crimes occur. In an effort to address why crime is unevenly and non-randomly distributed in time and space (Brantingham \& Brantingham, 1993), researchers make use of the Rational Choice Perspective (RCP; Cornish \& Clarke, 1986). Within RCP, criminal behaviour is framed as purposive behaviour, in the sense that people act in order to attain valued goals. Actions are selected from a range of (legal and non-legal) alternatives, based on an evaluation of the costs and benefits associated with a particular behavioural alternative. $\mathrm{RCP}$ is abstract, however, and "requires supplementary empirical content through specification of the relevant aims and choice situations" (Bernasco, 2009, p. 6). Crime researchers therefore increasingly supplement RCP with theoretical insights from Optimal Foraging Theory (OFT, see Brantingham, 2013; Johnson, 2014; Johnson, Summers, et al., 2009).

OFT is a behavioural ecology framework that studies how organisms' behavioural patterns of seeking, selecting, and processing food are the result of evolutionary and ecological forces (Stephens \& Krebs, 1986). OFT offers a wide range of specific hypotheses and mathematical models (Stephens et al., 2007; Stephens \& Krebs, 1986), with many a priori predictions bearing close similarity to criminal decisionmaking (Bernasco, 2009; Felson, 2006; Johnson, 2014; Johnson \& Summers, 2015). A growing number of crime studies have adopted a foraging perspective when exploring criminal activities, including studies regarding car theft (Brantingham, 2013), residential burglary (Johnson, Bowers, et al., 2009; Townsley et al., 2016), and maritime piracy (Marchione \& Johnson, 2013).

However, despite a rise in the number of studies, neither an overview of their main theoretical underpinnings and research findings exists, nor has an evaluation of the impact of OFT on criminology been attempted. Given the growing focus on OFT as a framework for structuring crime research, in this article we review the published OFT-inspired crime research. In doing so, we identify knowledge gaps, methodological limitations, and opportunities for future research. This article is structured as follows. First, OFT is discussed and framed within the criminological literature. Second, we present the search strategy and inclusion criteria employed to find and select relevant literature. Third, the selected studies' main objectives and findings are discussed. Finally, we conclude with a discussion of the findings and their implications for future criminological theory and research. 


\section{OPTIMAL FORAGING THEORY}

\section{Key elements}

Optimal Foraging Theory (OFT) is a behavioural ecology framework that studies the behaviour of animals when searching, selecting and processing food, while accounting for the costs and risks associated with their foraging behaviour (Davies et al., 2012; Stephens \& Krebs, 1986). All animals must eat in order to sustain themselves, but they differ in what food they choose to eat, as well as how they search for, acquire, and process food. OFT aims to explain these differences, assuming that ecological and individual constraints, in addition to evolutionary stress, pressures animals to optimize their foraging activities over extended periods of time.

The assumption of optimization is useful, since it allows relying on established methods of optimality modelling to predict how animals should behave (Parker \& Smith, 1990). Like all optimality models, models developed under OFT are comprised of three components that are brought together in an algebraic formula (Stephens \& Krebs, 1986, pp. 5-11):

- Decision: the problem or choice to be optimized. For example: how long to stay in a food patch.

- Currency: the quantity in which the decision outcomes are evaluated. For example: in many foraging decisions energy is the relevant currency, which is built up by food intake and spent by efforts to search and process food;

- Constraints: the limits on the available choice options and payoffs. For example: travel speed, hours of sunlight, food processing time, presence of competitors or predators.

OFT can be summarized as a framework of mathematical models and a priori hypotheses with regard to what animals forage (Charnov, 1976b; Sih \& Christensen, 2001), where animals forage (Nonacs, 2019), when animals forage and for how long (Charnov, 1976a; Marshall et al., 2013), how animals forage in groups (Giraldeau \& Pyke, 2019; Waite \& Field, 2007), and how animals move while foraging (Pyke, 2019a). Extensions of the classic models account for complications in foraging such as competition for and specialization in resources (Baird, 1991; Funk, 2019), the emergence of suboptimal behavioural strategies, and apparent irrational decision-making (Smith et al., 2016; Vasconcelos et al., 2015). Taken together, OFT offers a broad suite of behavioural rules and hypotheses, expressed in the language of mathematics, to address purposeful foraging behaviour.

\section{Illustration: The marginal value theorem}

To illustrate how in OFT hypotheses are derived from explicit propositions, we provide an example of a hypothesis rooted in the patch departure model (see Table 1). The hypothesis is known as the marginal value theorem (MVT; for a detailed description, see Charnov, 1976a). The MVT has been the subject of extensive study in behavioural ecology (Krebs et al., 1974; Watanabe et al., 2014; Zach \& Falls, 1976), and is regarded as the "most successful empirical model in behavioural ecology" (Ydenberg et al., 2007, p. 12). It describes the behaviour of organisms foraging for food in a patchy environment, and allows to predict how long a forager will stay in a location to consume food. The benchmark for deciding whether a given length of stay is optimal for the forager's fitness, is assumed to be its long-term energy intake. By maximizing long-term energy intake, the forager maximizes its evolutionary fitness.

In deriving hypotheses from the MVT, the constraints are crucial. For example, from assuming that a patch is depleted by consumption (i.e. food is not replaced immediately upon consuming it) so that the rate of caloric intake drops over time, it follows that there must come a time when it is more efficient to try to find another patch in the environment than to continue foraging at an ever-decreasing gain rate in 
the current patch. Other assumptions crucial for deriving the hypothesis relate to the search costs, the random nature of patch searches, and the similarity of the patches in terms of the resources they provide. Some assumptions are evidently unrealistic, but are required to derive a straightforward hypothesis.

\section{[INSERT TABLE 1 AROUND HERE]}

\section{Application to criminal behaviour}

OFT has been successfully used to study contemporary human behaviour, such as the way humans process digital information (Pirolli \& Card, 1999), or as a model for shopping behaviour (Rajala \& Hantula, 2000). The introduction of the metaphor that likens offenders' behaviour to those of foraging animals goes back to a number of works in criminology. As far as the authors are aware, Fagan and Freeman (1999) were the first to refer to foraging in a criminological context by comparing the switching between legal and illegal income-generating activities with the foraging decisions animals face. ${ }^{i}$ Later, Johnson and Bowers (2004b) compared burglars' subsequent target choices with foraging strategies, while Felson (2006) noted the similarities between aspects of criminal decision-making and questions addressed in animal ecology. Bernasco (2009) specifically illustrates how OFT can help to think about the way crimes are carried out, outlining several established foraging models and how they can be applied to crimes against property.

\section{METHOD}

We synthesize the extant literature by undertaking a 'systematic search and review' (Grant \& Booth, 2009). This type of review combines the strengths of a comprehensive search and selection process with a more qualitative process of appraisal, synthesis and analysis.

Studies are eligible for inclusion if they meet the following criteria:
a. Theory:
studies need to explicitly mention (Optimal) Foraging Theory.
b. Subject:
studies should focus on environmental criminological themes, either focusing on crime or crime control.
c. Study design: only empirical studies are included, with no distinction in terms of the methodology used.

d. Medium: $\quad$ PhD theses and working papers are excluded.

To identify relevant studies, we searched Google Scholar (GS) and Web of Science (WoS). We selected GS because this database consistently returns a higher number of publications compared to traditional scientific databases, especially for the social sciences (Martín-Martín et al., 2018). However, the lack of quality control and clear indexing guidelines suggest it should be used in combination with controlled databases such as WoS (Halevi et al., 2017). For WoS, searches were conducted on June $11^{\text {th }} 2019$ using the following key words: forag* AND (crim* OR delinq* OR offen*). A total of 189 hits were obtained this way. Since the use of Boolean operators is somewhat inconsistent for GS (Halevi et al., 2017), several separate search tasks were completed in this database using combinations of the following key words: forager/foraging/forage; crime/criminal; delinquent/delinquency; offender/offending/offense. GS was consulted on June $12^{\text {th }} 2019$. Each combination resulted in an extraordinary amount of hits. ${ }^{\text {ii }}$ This is partly due to the fact that GS automatically searches for matching and similar meaning words. However, the relevance of retrieved studies quickly dropped after the first hundred studies. For each combination of key words, only the first 250 studies were evaluated (as ranked by GS), which should ensure that the majority of relevant studies are included. In order to increase useful hits, GS' cited by feature was employed to find studies that referred to studies that matched the researchers criteria. To see 
whether studies matched the criteria for inclusion in this review, they were evaluated based on title, abstract, and contents (in that order). Both databases combined yielded 32 studies that matched all of the criteria outlined above. Searches and selections were conducted by the second author.

\section{RESULTS}

The findings are presented according to the focal decision being modelled. For each category, the research questions and underlying theoretical models are explained, followed by a discussion of the selected studies' research designs, and a summary of their main findings. All included studies are summarized in Table 1.

\section{[INSERT TABLE 2 AROUND HERE]}

\section{Spatiotemporal clustering of crime and crime-control}

\section{Research questions}

Most applications of OFT to offending investigate the spatiotemporal concentration of crime, in particular the well-established phenomenon of repeat and near-repeat victimization: in the wake of an offence, the risk of victimization is initially elevated both for the original target and for nearby targets, but drops back to its baseline level over time (Johnson \& Bowers, 2004a, 2004b; Johnson, Bowers, et al., 2009). The phenomenon makes offences cluster in space-time. It has been demonstrated that in the majority of repeat and near repeat offences, both the original and the subsequent offence involve the same offenders (Bernasco, 2008; Johnson, Summers, et al., 2009). In other words: the events that represent repeat and near-repeat victimisation are also instances of repeat and near-repeat offending. An offender who repeatedly victimises the same or nearby targets, bears similarity to a foraging animal that is harvesting a patch, as described in the MVT (Charnov, 1976a). The MVT is thus a natural candidate to help frame predictions on offender behaviour. For example, can we predict how long an offender will continue offending in some place before moving on to a more lucrative location? Whereas in the OFT assumptions are typically spelled out explicitly, the applications of OFT to offending are not all equally explicit about these assumptions.

First, in line with RCP, it is assumed that offender decision making involves weighing benefits, costs and risk, with offenders preferring alternatives that maximize the amount of resources obtained, while minimizing effort and the risk of apprehension (see also the section on Location choice). Second, targets that are proximate to each other are on average also more similar, reflecting the first law of geography (Tobler, 1970). Third, the foraging perspective applied here places emphasis on the fact that offenders learn about their environment after committing the first offense in a particular location (Bernasco et al., 2015; Johnson \& Bowers, 2004b; Johnson, Bowers, et al., 2009; Rey et al., 2012; Rosser et al., 2017; Sidebottom, 2012; Youstin et al., 2011). Combined with the previous assumption, this acquired knowledge reduces uncertainty for the offender about targets in the vicinity of previously targeted resources. This is especially true shortly after the first offense, since circumstances are less likely to have changed by then (Bernasco et al., 2015). This is similar to the sampling behaviour of animals, exploring environments to evaluate whether they are worth the time, risk, and effort (Stephens \& Krebs, 1986, p. 81). Finally, the decay in risk over time is believed to be primarily the result of an increased risk of detection as time goes on, due to an increase in police attention or citizen vigilance (Hering \& Bair, 2014; Johnson \& Bowers, 2004b; Johnson, Bowers, et al., 2009; Rosser et al., 2017; Wheeler, 2012; Youstin et al., 2011). Additionally, as offenders keep foraging in the same area resources become scarcer over time, which prompts offenders to move on to richer areas (Chainey \& Silva, 2016; Hering \& Bair, 2014; Johnson, Bowers, et al., 2009). Combined, this leads to the hypothesis that optimally 
foraging offenders will continue offending in the same area after successfully committing a crime, until the perceived costs and risks outweigh the benefits.

One study (Wheeler, 2012) addresses the related but different research question of whether the location where an offender commits crime is conditional on where they live. It uses address changes of known offenders to set up a quasi-experimental design that compares offense locations of the same offender before and after their address change, and finds that offenders' home locations have a significant but small effect on where they offend. The study engages with OFT when discussing the tendency of offenders to re-offend where they offended before, but does not elaborate in depth how offender home locations would fit in the OFT framework. The concept of central place foraging (Orians \& Pearson, 1979), in which foraging is constrained by the need for the animal to return a fixed anchor point (e.g., a nest, hole or den), might have proven useful.

Another study focuses on spatiotemporal patterns of crime-control instead of criminal activity (Sorg et al., 2017). The study evaluates police behaviour during hot spot patrols. Hot spot policing is the result of the well validated observation that crime is concentrated in a small number of geographic units (Weisburd, 2015). To increase the likelihood of reducing aggregate crime levels, police efforts should concentrate on those high-crime areas. However, research suggests that the deterrent effect of police deployment decays over time (e.g., Sherman, 1990). Sorg et al. (2017) examine the potential influence of changes in police effort on deterrence decay, and draw on MVT to hypothesise that officers might leave their assigned hot spots to patrol in other areas as time moves on, a mechanism they term dosage diffusion.

While there are many studies that employ OFT as a framework to investigate spatiotemporal patterns in criminal and law enforcement activity, these differ in terms of how central OFT is to the research and which specific hypotheses are being tested. Li et al. (2014) briefly refer to OFT as an explanatory framework for temporally constrained clusters of crime, but do not explicitly test hypotheses from OFT. $\mathrm{Yu}$ and Maxfield (2013) state that foraging offenders are a possible mechanism in near-repeat victimization without much clarification. Furthermore, both Bernasco et al. (2015) and Nobles et al. (2016) claim that OFT suggests that offenders should learn from previous offenses. Sorg et al. (2017) explicitly operationalise the three components of optimality modelling (decision, currency and constraints), which no other study does. Direct tests of foraging behaviour either measure the extent of spatiotemporal clustering of crime (Chainey et al., 2018; Chainey \& Silva, 2016; Johnson \& Bowers, 2004b; Porter \& Reich, 2012; Rey et al., 2012; Townsley \& Oliveira, 2015), or whether individual offenders tend to return to previously target areas (Bernasco et al., 2015; Hering \& Bair, 2014; Porter \& Reich, 2012). The distinction between both approaches follows from the type of data available, i.e. whether the data are aggregated or associated with individuals. Not all studies aim to test hypotheses from OFT. More commonly, they use OFT to inform predictive models of crime (Gerstner, 2018; Glasner et al., 2018; Johnson, Bowers, et al., 2009; Rosser et al., 2017).

\section{Research designs}

The majority of selected studies rely on crime data recorded by law enforcement agencies or international organisations (Braithwaite \& Johnson, 2015; Chainey et al., 2018; Chainey \& Silva, 2016; Gerstner, 2018; Glasner et al., 2018; Hering \& Bair, 2014; Johnson \& Bowers, 2004b; Johnson, Bowers, et al., 2009; Nobles et al., 2016; Rey et al., 2012; Rosser et al., 2017; Townsley et al., 2016; Wang \& Liu, 2017; Youstin et al., 2011). In a number of studies data on cleared offenses were used (Bernasco et al., 2015; Hering \& Bair, 2014; Johnson, 2014; Porter \& Reich, 2012; Wheeler, 2012), which allowed to link criminal events to individual offenders. One study conducted a victimization survey (Sidebottom, 2012). Another study (Sorg et al., 2017) employed data on the number of police-initiated activities undertaken. 
With the exception of Sorg et al. (2017), studies in this category are crime-oriented and predominantly focus on acquisitive crime types, such as maritime piracy (Townsley et al., 2016), with the bulk of these studies directing their attention to (residential) burglary either exclusively (Bernasco et al., 2015; Chainey et al., 2018; Chainey \& Silva, 2016; Gerstner, 2018; Glasner et al., 2018; Hering \& Bair, 2014; Johnson, 2014; Johnson \& Bowers, 2004b; Johnson, Bowers, et al., 2009; Nobles et al., 2016; Rey et al., 2012; Rosser et al., 2017; Sidebottom, 2012) or in combination with other crime types (Hering \& Bair, 2014; Johnson, Bowers, et al., 2009; Porter \& Reich, 2012; Wheeler, 2012). Some studies focus on a combination of crime types such as Youstin et al. (2011) who employed data on shootings, robbery, and car theft, while Hering and Bair (2014) combine non-acquisitive crime (arson) with acquisitive crime types (i.e., robbery, residential, vehicular and commercial burglary). Braithwaite and Johnson (2015) focus on terrorist insurgency.

A variety of analytical approaches are applied in the selected studies with a predominance of regression analyses (Braithwaite \& Johnson, 2015; Gerstner, 2018; Li et al., 2014; Nobles et al., 2016; Wheeler, 2012; Yu \& Maxfield, 2013), applications of the Knox (1964) test for detecting space-time interactions (Johnson \& Bowers, 2004a, 2004b; Johnson, Summers, et al., 2009; Townsley \& Oliveira, 2015; Wang \& Liu, 2017; Youstin et al., 2011), applications of Ratcliffe's (2009) near repeat calculator (Chainey et al., 2018; Chainey \& da Silva, 2016; Chainey \& Silva, 2016; Glasner et al., 2018; Youstin et al., 2011), and predictive crime mapping (Gerstner, 2018; Glasner et al., 2018; Johnson, Bowers, et al., 2009; Rosser et al., 2017). Two studies relied on kernel density estimation to detect crime clusters (Chainey et al., 2018; Porter \& Reich, 2012). Correlational analysis was sometimes applied (Johnson \& Bowers, 2004b; Sidebottom, 2012). Less-used approaches involve ANCOVA (Sorg et al., 2017), spatiotemporal cluster analysis (Hering \& Bair, 2014), discrete spatial choice analysis (Bernasco et al., 2015), conditional spatial Markov Chains (Rey et al., 2012), and comparing probability density functions with exponential and power law distributions (Johnson, 2014).

\section{Discussion of study results}

The findings of the selected studies focusing on criminal activity confirm that crime clusters in space and time (Chainey \& Silva, 2016; Johnson \& Bowers, 2004b; Porter \& Reich, 2012; Rey et al., 2012; Townsley et al., 2016), and that this observation is most likely the result of offenders deploying optimal foraging strategies (Bernasco et al., 2015; Johnson \& Bowers, 2004b), especially at smaller temporal scales. Braithwaite and Johnson (2015) found that both time-invariant risk heterogeneity and offenders returning to previously targeted areas are at play. Interestingly, Hering and Bair (2014) found results inconsistent with OFT: offender activity becomes more clustered as time progresses instead of becoming more dispersed.

A single study (Johnson, 2014) empirically examines the applicability of random walk models to sequential inter-crime trips of UK residential burglars. Random walks are mathematical models of moving objects that have been used to describe the search paths of foraging animals. When describing and theorizing animal foraging patterns, scholars in ecology often refer to and find evidence for two different types of random walks: Brownian motion and Lévy flight (e.g., Humphries et al., 2010). Brownian motion is characterized by small variations in step length and appears optimal in environments where food is abundant, whereas Lévy flight is characterized with occasional large jumps and appears optimal in sparse environments. Both types of random walk generate movement patterns distinct from central place foraging, which is typical of the movement of animals that repeatedly return to an anchor point (e.g., birds feeding their offspring) and also characterizes human mobility (Song et al., 2010). Johnson (2014) compares the empirical distributions of distances between burglary events to those generated by Lévy flight, by Brownian motion, and by simple central place foraging. The findings suggest that central place foraging strategies are insufficient to explain the observed distance 
distribution. Additionally, Johnson (2014) suggests that offenders most likely do not unequivocally stick with one of both random walk strategies (Lévy flight or Brownian motion).

Finally, the results of the only study addressing law enforcement activity suggest that the amount of time spent patrolling outside assigned areas increases as time goes on (Sorg et al., 2017). Additionally, they found that this process is hastened in areas that are faced with relatively little crime, or in areas that are adjacent to high-crime areas, a result that is in line with the qualitative predictions of MVT (Charnov, 1976a).

\section{Location choice}

\section{Research questions}

Five of the selected studies reference OFT to explain how offenders choose where to offend, ranging from larger areas to individual households (Bernasco, 2006, 2010; Bernasco \& Nieuwbeerta, 2005; Medel et al., 2015; Pires \& Clarke, 2011). Similar to a rational actor, an optimal forager prefers targets that maximize gains, while minimizing effort and risk. By extension, areas seeming to contain valuable items that are in close proximity and are relatively easy to acquire will be more attractive. It follows that if offenders are assumed to behave like optimal foragers, they will attempt to maximize their revenues by selecting areas that are relatively easy to navigate to, seem affluent and appear to be low in surveillance so that the risk of apprehension is small.

\section{Research designs}

Four studies relied on recorded crime data by law enforcement agencies or municipal administrations (Bernasco, 2006, 2010; Bernasco \& Nieuwbeerta, 2005; Medel et al., 2015). Pires and Clarke (2011) relied on secondary data on bird species sold at an illegal pet market. In order to account for individual offender characteristics, a number of studies used data on cleared offenses (Bernasco, 2006, 2010; Bernasco \& Nieuwbeerta, 2005). Three studies focused on residential burglary (Bernasco, 2006, 2010; Bernasco \& Nieuwbeerta, 2005), one on drug smuggling, and one on parrot poaching (Pires \& Clarke, 2011).

The five studies considered in this section applied three different analytical approaches. The first approach applies the discrete spatial choice framework to burglars' location choices (Bernasco, 2006, 2010; Bernasco \& Nieuwbeerta, 2005). The second approach (Medel et al., 2015) used network analysis to investigate drug smuggling routes. Finally, Pires and Clarke (2011) correlated the number of parrots for each species found at an illegal pet market with a number of attributes expected to impact their desirability.

\section{Discussion of study results}

Study results are largely in line with OFT-inspired predictions. Burglars prefer areas that contain many dwellings (Bernasco, 2010; Bernasco \& Nieuwbeerta, 2005), appear low in surveillance (Bernasco \& Nieuwbeerta, 2005), contain more highly-valued properties (Bernasco, 2010), are physically accessible (Bernasco, 2006; Bernasco \& Nieuwbeerta, 2005), and are in close proximity to offenders' homes (Bernasco, 2006, 2010). Medel et al. (2015) demonstrated that drug smuggling routes are selected to maximize profits and minimize costs and risks. Finally, it seems that parrot species that occur more often at illegal pet markets is likely the result of their overall abundance, accessibility to humans, and overall enjoyability as pets, indicating that parrot poachers might be acting as optimal foragers (Pires \& Clarke, 2011). 


\section{Target choice}

\section{Research questions}

Two of the selected studies (Badiora, 2017; Brantingham, 2013) investigates offender target choices and explicitly refer to the classic prey choice model (Charnov, 1976b). This model explains why animals would eat some types of prey while ignoring others-so-called individual specialisation (Araújo et al., 2011). The model assumes discrete prey types that differ in terms of value, the effort it takes to capture and process them and their abundance in the environment, and foragers are supposed to maximize the average gains per unit of time.

Applied to car theft, each make model can be ranked according to the ratio between its market value and effort it takes to steal. Furthermore, car thieves should try to amass as much value as possible relative to effort by being selective in what make models they steal. When encountered, the highest-ranked make model should always be stolen given the opportunity. Since it is the best possible make model to steal, the time and effort spent can never be lost because there is no better alternative to spend it on. In fact, if this make model is abundant enough, there is no reason to pursue any other type. Such opportunities are rare, however, so that a car thief who specializes entirely on this make model will be left with few occasions to steal. Consequently, optimally foraging car thieves will add inferior car types to their "diet", until doing so would no longer increase the average gains per unit of time.

The prey model thus predicts that offender specialization is normal, and that offenders should only prefer a wider range of target types when preferred targets become scarce (Araújo et al., 2011). This is a combination of rational decision-making (select the option that yields the greatest benefits relative to the costs) and the principle of lost opportunity (ignore targets if the probability of encountering highervalue targets is sufficiently high). This also leads to the somewhat unintuitive prediction that the inclusion of a particular type of target is independent of how abundant it is, instead depending entirely on the abundance of higher-ranked targets.

\section{Research designs}

Both studies examine car thieves' choice to steal different car make models in Los Angeles, USA (Brantingham, 2013) and Lagos, Nigeria (Badiora, 2017). Instead of more detailed predictions that can be generated under Charnov (1976b) model, both studies use recorded crime data to test a conservative null hypothesis that if all make models are ranked evenly (i.e., if there is no preference for one model over another), each car type should be stolen about as frequently as they occur in the environment. This corresponds to a forager who targets opportunistically (Araújo et al., 2011). Both studies rely on correlational methods to evaluate their hypothesis.

\section{Discussion of study results}

Both studies (Badiora, 2017; Brantingham, 2013) found a significant positive relationship between car theft and abundance, but also found that some models were targeted more often than expected based on their relative abundance (and vice versa). The study of Brantingham (2013) additionally found that the higher theft rates of these models are associated with higher expected values, but not with their handling costs (proxied by average break-in times). This was not tested in the study of Badiora (2017). Both studies conclude that abundance is likely the primary predictor of car thieves' target choices, yet is insufficient on its own to explain theft rates. These findings suggest that offenders might have different target preferences, but do not offer conclusive evidence to suggest that individual specialisation is widespread among offenders like this is the case in natural populations (Araújo et al., 2011; Bolnick et al., 2003). 


\section{Offender mobility}

\section{Research questions}

Finally, one study examined the mobility of offenders and how this impacts earnings (Morselli \& Royer, 2008). In this study, the authors refer to what Felson (2006) calls strategic foraging, claiming that "offenders will forage in patches somewhat farther away if additional booty makes it worth their while" (pp. 265). Mobility was operationalized as the perimeter wherein offenders are active (akin to the operational range of foraging animals, see Felson, 2006). This is similar to questions in behavioural ecology where animals searching for patches containing food should prefer areas that contain many food items relative to the time and effort spent searching for them (MacArthur \& Pianka, 1966). Travel distance is a cost, and this cost must be compensated by the expected value of these areas.

\section{Research designs}

Morselli and Royer (2008) collected data on mobility and earnings through face-to-face interviews with incarcerated offenders in Quebec, Canada. Data were analysed through regression modelling.

\section{Discussion of study results}

Their findings (Morselli \& Royer, 2008) suggest that increased mobility is compensated by higher reported earnings, but that this relationship is stronger for predatory crime types (e.g., burglary or robbery) than for market crimes (e.g., drug dealing or fencing).

\section{DISCUSSION AND CONCLUSION}

The purpose of this article was to provide an overview of OFT-inspired empirical crime research, and to explicitly focus on the underlying theoretical models and on the findings generated. While the 32 selected studies are diverse, most of the OFT-inspired crime research applies foraging models to account for spatiotemporal clustering of crime (24 studies). The other three research topics-location choice (five studies), target choice (two studies), and offender mobility (one study) — have been studied infrequently from a foraging perspective. The dominance of spatiotemporal phenomena in the application of OFT in criminology is additionally highlighted by the observation that studies on "location choice" and "offender mobility" in fact also address spatiotemporal phenomena, including spatiotemporal clustering. The only difference is in the unit of analysis. Research on "spatiotemporal clustering" uses spatial entities as the unit of analysis, whereas location choice and offender mobility research use individual offenders as the unit of analysis. Ultimately, all three categories aim to explain how spatiotemporal crime patterns arise in the aggregate. From this perspective, the distinction in different topics we made is less clear-cut than it seems.

In conclusion, the application of OFT seems almost completely restricted to explaining spatiotemporal distributions of crime. It may further be noted that certain environmental criminological topics that could potentially be addressed from an OFT perspective are not included in any of the selected studies. For example, how offenders respond to variations in law enforcement, such as policing strategies, has not been studied systematically from a foraging perspective, although it has been suggested that offenders may displace their criminal activities in response to increased police activity. Answers to the research question could well profit, however, from models that specify how animals mitigate predation risk (Verdolin, 2006). Another topic not addressed from the OFT perspective is cooperation and competition amongst offenders. Where models of social foraging account for effects of intra-species cooperation and competition (Giraldeau \& Caraco, 2000), cooperation and competition between offenders has not been addressed in any of the selected crime studies. To the extent that these topics capture the interest of crime researchers, OFT may provide a yet untapped but promising theoretical framework. Although spatiotemporal studies dominate OFT-inspired empirical crime research, the reverse is not true. In 
criminological research that addresses spatiotemporal questions, neither OFT nor RCT are the dominant theories. Instead, scholars predominantly rely on the geometry of crime (Brantingham et al., 2016), a subset of Crime Pattern Theory (CPT; Brantingham \& Brantingham, 2008). The geometry of crime does not explicitly challenge any propositions of OFT, but there appears to be frictions between the two perspectives. OFT is a generic theory of behaviour with universal claims, whereas CPT is a criminological theory that focuses on criminal behaviour. OFT is built on first principles only, whereas CPT builds on empirical regularities from other disciplines such as the concepts of activity space and awareness space. Because of these differences, both theories offer different explanations for the same empirical phenomena. For example, OFT explains the preference of offenders to commit crimes near their homes as an outcome of optimization of effort investment, whereas CPT explains it as a consequence of the fact that humans spend most of their time relatively close to their homes and therefore have more knowledge of nearby than of distant criminal opportunities.

OFT is more closely related to RCP than it is to CPT. Both OFT and RCP have their roots in neoclassic economics and share the assumption of utility maximizing behaviour. This begs the question why scholars would turn to OFT when they have had RCP for decades already. For example, although RCP acknowledges the dynamic nature of decision-making, allows for constraints to change over time, and addresses intertemporal choice, why have many researchers interested in patterns across series of offenses been inspired by foraging models instead? The answer may be related to the fact that most individual-based crime research focuses on serial crime types, whereby one offender commits multiple offenses. This aligns well with the emphasis in OFT on the long-term fitness consequences of behaviour over sequences of decisions. Methodologically, it speaks in favour of studies whereby a small number of animals are observed repeatedly (e.g., Araújo et al., 2008; Tinker et al., 2012), which contrasts with crime research where often police recorded crime data on a large number of offenders are available, but who are on average observed infrequently (Johnson, 2014). Finally, there is a focus on acquisitive crime, neglecting other crime types (but see Braithwaite \& Johnson, 2015; Hering \& Bair, 2014). This is unsurprising, since it is more straightforward for acquisitive crime to define the currency components, integral to any OFT model, of the crime-foraging problem than for other crime (but see, e.g., Burgason \& Walker, 2013 who discuss an approach to identify currency for internet sex offending). Taken together, it seems that the influence of OFT has been strongest for the study of repeat acquisitive offending.

Nonetheless, there might be some concerns to comparing the behaviour of offenders with that of foraging animals. First, for animals, the only alternative to eating is death. Offenders are not obliged to commit crime and have legal and non-legal alternatives to choose from. Even so, OFT has been successfully applied outside biology to human decision-making and behaviour that does not involve death as the ultimate alternative (Pyke \& Stephens, 2019). In fact, offenders' decision-making to engage in legal or non-legal activities is acknowledged as a proper foraging problem that exhibits similarities with animals choosing between prey types or alternating between patches (Fagan \& Freeman, 1999). Therefore, this should not prevent crime researchers from harnessing OFT to study offender behaviour. In addition, it seems appropriate to assume that optimal criminal choice strategies are more likely to thrive than suboptimal strategies. Offenders who consistently make suboptimal choices are probably more likely to be arrested and convicted, and also less likely to survive the competition with more successful offenders. Second, for many animals the search for food is a full-time activity, while offending is often part-time and discretionary (Bernasco, 2009; Pires \& Clarke, 2011). However, efficient foraging increases fitness since excess time and energy can be spent on reproductive behaviour. This implies that offending does not have to be time-consuming in order to be studied using OFT. Finally, for animal diet choices the currency is seemingly straightforwardly identified, often the calorific intake rate over time (Charnov, 1976b). For offenders, pay-offs might not be apparent, especially when 
non-monetary gains are involved such as status or thrill-seeking (Goodwill, 2014). This challenges crime researchers to establish currencies or adopt sensible proxies thereof. In doing so, crime researchers could learn from the iterative approach OFT-researchers adopted to establish (more) valid currencies (Burgason \& Walker, 2013; Pyke, 2019b). In light of these concerns, we suggest to refer to future OFT instalments in crime research as OFT-inspired instead of considering those as strict tests of OFT to offending and law enforcement.

Despite these concerns, it cannot be ignored that research into animal behaviour has proven to be essential for advancing our understanding of human behaviour (Hager, 2010). For example, our insight into human individual, social, and reproductive behaviours has dramatically improved due to research into these behaviours in nonhuman primates (Brosnan, 2013; Burkart et al., 2018; Lindegaard et al., 2017; Muller \& Wrangham, 2009). Indeed, OFT is increasingly being applied with success outside biology in a variety of disciplines that, at face value, bear little resemblance to the foraging decisions for which OFT was initially developed (Pyke \& Stephens, 2019). For crime research in particular, the conceptual similarities between the situations faced by offenders and those encountered by foraging animals are apparent and harnessing OFT offers important advantages to crime researchers. First, a major advantage of applying OFT to environmental criminological questions lies in the fact that criminology lacks a theoretical framework that is formulated in terms of mathematical propositions and is able to explain how, when, and where behavioural strategies are enacted (Bernasco, 2009). OFT provides such a theoretical background while also explaining why these patterns occur based on ecological and individual factors in addition to evolutionary stress. Therefore, it extends current criminological theory, in particular RCP, by offering criminologists a theoretical framework to translate qualitative hypotheses into quantitative predictions. Second, the hypotheses formulated in OFT are compatible with hypotheses that have been formulated and tested in criminology, such as the often observed pattern whereby offenders commit offenses close to their home (e.g., Bernasco, 2006), and the phenomenon that crime clusters in space and time (Johnson \& Bowers, 2004b). OFT is also appealing since it does neither assume that decision-making is perfectly calculated or deliberate nor that foragers are aware of the complex cognitive processes underlying their decision-making (Stephens et al., 2007). Furthermore, OFT is a theoretically rich and empirically vibrant field whose continuing theoretical, methodological, and analytical advances could inspire and enrich crime research. If nothing more, the heuristic value of the wide range of hypotheses that have been formulated through the years have already proven to be productive in generating new research directions for crime research (Brantingham, 2013). For example, the attention of OFT to how foraging decisions evolve over time has led to novel insights in the generation of spatiotemporal crime patterns (e.g., Johnson, Bowers, et al., 2009). That is, repeat offending may be the result of offenders learning about future target opportunities nearby initial targets in a process similar to that of how foraging animals detect new prey. Finally, from a pragmatic point of view, the metaphor of the foraging criminal provides a highly visual image aiding communication towards law enforcement agencies (Pease, 2014). Taken together, OFT is not only compatible with extant criminological theory and research hypotheses in environmental criminology but also extends current theory within environmental criminology, offers crime researchers a mathematical framework with versatile modelling options, and could serve as inspiration for future crime research.

Despite a growing number of crime studies referencing OFT, there is still theoretical work necessary to employ behavioural ecological insights in criminology beyond its heuristic value. A number of steps might be undertaken to further develop OFT as a framework in criminology. First, if the strength of OFT lies in the "specification of the relevant aims and choice situations" (Bernasco, 2009, p. 6), crime researchers could be more explicit in the choice situations they are modelling, which currency foragers are expected to maximize, and under which constraints they operate. None of the selected studies elaborated on these core elements of optimality modelling which are central to OFT. In fact, studies that 
apply OFT rarely articulate why it is preferred over RCP. Two crime foraging studies that use agentbased modelling (ABM) to test OFT hypotheses, both of which were excluded from the literature review because they are not empirical studies (Malleson, 2012; Malleson et al., 2013), are a case in point. Both studies present the foraging criminal as an alternative to the rational offender, but it is not clear why one was chosen over the other. To illustrate, Malleson (2012, p. 8) states that "[b] urglars act as 'optimal foragers' when they choose target areas because their decision is based on an analysis of potential rewards against risks" (for a similar description, see also Malleson, 2012). Moreover, this approach places considerable emphasis on the process of arriving at a particular decision (i.e., the analysis of rewards against risks), which is but one aspect of the concept of rationality in behavioural ecology (Kacelnik, 2006).

Second, researchers could leverage the interrelations between foraging models and different stages of offender decision-making. Bernasco (2006) noted the similarities between the choice process of residential burglars and those of foraging animals. Burglars are assumed to follow a spatially structured, sequential, and hierarchical decision process in selecting their targets (Cornish \& Clarke, 1986), which corresponds to first selecting an area and a suitable target second (Vandeviver \& Bernasco, 2019). This resembles animals' decision hierarchy (Stephens, 2008), whereby they first select a foraging patch, which influences their subsequent prey selection in the patch (Charnov, 1976b) and how long they keep foraging in the patch (Charnov, 1976a). The interrelations between subsequent choices have not been evaluated from an optimal foraging perspective in criminology so far, but could help in the development of a comprehensive offender decision-making framework.

Finally, the relationship between evolutionary fitness and economic utility could be elaborated. Although fitness and utility are closely related concepts with similar roles in their respective disciplines (Schulz, 2014), they cannot be unambiguously equated with each other (Binmore, 2012). In fact, the relation between both concepts is subject of behavioural ecological inquiry (Westneat \& Fox, 2010), in part because the (a posteriori) utility maximization approach allows the modelling of trade-offs between, for example, safety and food intake (Stephens \& Krebs, 1986). Clarifying if, and under which circumstances, principles of fitness maximization can be interpreted as utility maximization will further guide crime researchers' decision when it is appropriate to apply models rooted in OFT to offender behaviour. Similarly, clarifying the evolutionary basis of rationality helps integrate criminology with other disciplines.

At the same time, certain methodological issues specific to crime research may limit the potential of applying OFT to criminological themes. Studies in behavioural ecology often collect data by directly observing the species' behaviour in situ (e.g., Tinker et al., 2012). Due to the nature of criminology's research subject, however, direct observation of the foraging process is restricted (van Gelder \& Van Daele, 2014), although some notable exceptions exist, such as the research on shoplifting by Dabney et al. (2004). The limitation of not being able to observe criminal behaviour directly forces crime researchers to infer offenders' decisions from aggregated recorded crime data. Although some researchers circumvent this by using data on cleared offenses (Johnson, 2014), this might erroneously misclassify foraging walks since caught offenders likely differ from unknown offenders (Pease, 2014), in addition to the possibility that the exclusion of attempts could bias results towards longer inter-crime distances. Moreover, given the low clearance rates of detected crimes in most Western countries, the use of data based on cleared offenses limits the generalizability and applicability of research results to crimes committed by unknown offenders.

Triangulating data sources might prove valuable to offset inherent biases of one particular data type, for example by setting up offender-based study designs. To illustrate, interviews with incarcerated offenders revealed that offenders deliberately disperse activity as time goes on in order to decrease the risk of 
detection or apprehension, an observation that is in line with predictions from OFT (Summers et al., 2010). Additionally, the use of DNA data holds great potential to study spatiotemporal behaviour of individual (unknown) offenders in general (Bernasco et al., 2016; De Moor et al., 2018; Lammers, 2014; Lammers \& Bernasco, 2013), and predictions from OFT in particular.

Finally, recent extensions of OFT might prove valuable for developing criminological theory, with some contemporary issues showing similarity to issues in criminology. Criminological research into offender spatial decision-making increasingly accounts for between-offender differences, for example in the study of variation in journeys to crime (Townsley \& Sidebottom, 2010; Van Daele, 2010) or in crime location choice (Frith et al., 2017; Townsley et al., 2016). Similarly, studies in animal ecology increasingly acknowledge diet variation among members of the same species (individual specialisation; e.g., Bolnick et al., 2003; Cantor et al., 2013; Tinker et al., 2012). Theoretical and methodological innovations from these studies might provide valuable insights for crime researchers. In particular, OFT offers a framework for explaining and quantifying between-individual differences in prey selection (Araújo et al., 2011; Bolnick et al., 2003). For example, individual specialisation in prey selection may arise due to ecological opportunities, competition for shared resources, or predation risk (Araújo et al., 2011; Bolnick et al., 2003). Each hypothesis yields different qualitative and quantitative predictions that can be evaluated by custom metrics (Almeida-Neto et al., 2008; Almeida-Neto \& Ulrich, 2011; Roughgarden, 1972; Simpson, 1949).

Unavoidably, this study suffers from limitations. Although objective selection criteria for the included studies were used, they were applied by a single author only and not subjected to inter-rater reliability assessment procedures. In addition, it is possible that bias occurred due to our choice for only two bibliographic databases. The decision to only include empirical research resulted in the loss of some interesting theoretical work on crime foraging (Burgason \& Walker, 2013) and a number of OFTinspired ABM-studies of crime (Brantingham \& Tita, 2008; Malleson, 2012; Malleson et al., 2013; Malleson et al., 2012; Pitcher \& Johnson, 2011). Although not the focus of this review, these studies could inspire future crime researchers. For example, Burgason and Walker (2013) articulate how crime researchers might establish the optimization components central to a foraging-inspired model of internet sexual offenders, and Brantingham and Tita (2008) demonstrate how OFT-inspired mathematical models and ABMs generate quantitative predictions of offender movement. Keeping these limitations in mind, the divergent focus of the selected foraging studies, combined with the observation that OFT is still peripheral to criminology, leads us to believe that this review was adequate to provide a comprehensive overview of the current state of the field.

In conclusion, the introduction of OFT in environmental criminology has generated a large volume of novel empirical research, illustrating that OFT can inspire criminological research and offer a mathematical framework to improve our understanding of offender decision-making. Nevertheless, the extent to which criminological theory development has benefitted from these applications of OFT to crime research remains limited. Indeed, we rarely observed theoretical innovation in any of the identified studies. In the large majority of OFT-inspired crime research, OFT was only used as an interpretative framework for understanding the spatiotemporal patterns produced by repeat and near repeat victimisation, leaving other promising applications of OFT to crime and crime control unexplored. Despite a decade of OFT-inspired research, our conclusion echoes Bernasco's (2009) conclusion that there remains much potential for future OFT-inspired research. Researchers should prioritize solidifying the theoretical foundation of OFT in criminology and exploring anchor points between behavioural ecology, evolutionary theory, and crime science. Additionally, contemporary extensions to OFT and tools developed for the study of animal foraging decisions, in particular specialisation in prey choice, show great potential for application to criminal foraging problems. By taking advantage of theoretical 
and methodological advances in the foraging literature, a greater understanding of offender decisionmaking may develop.

\section{REFERENCES}

Almeida-Neto, M., Guimarães, P., Guimarães Jr, P. R., Loyola, R. D., \& Ulrich, W. (2008). A consistent metric for nestedness analysis in ecological systems: reconciling concept and measurement. Oikos, 117(8), 1227-1239. https://doi.org/https://doi.org/10.1111/j.0030-1299.2008.16644.x

Almeida-Neto, M., \& Ulrich, W. (2011). A straightforward computational approach for measuring nestedness using quantitative matrices. Environmental Modelling \& Software, 26(2), 173178. https://doi.org/https://doi.org/10.1016/j.envsoft.2010.08.003

Araújo, M. S., Bolnick, D. I., \& Layman, C. A. (2011). The ecological causes of individual specialisation. Ecology Letters, 14(9), 948-958.

Araújo, M. S., Guimarães, P. R., Svanbäck, R., Pinheiro, A., Guimarães, P., Reis, S. F. d., \& Bolnick, D. I. (2008). Network analysis reveals contrasting effects of intraspecific competition on individual vs. population diets. Ecology, 89(7), 1981-1993.

Badiora, A. I. (2017). Ecological Theories and Spatial Decision Making of Motor Vehicle Theft (MVT) Offenders in Nigeria. Journal of Applied Security Research, 12(3), 374-391.

Baird, P. H. (1991). Optimal Foraging and Intraspecific Competition in the Tufted Puffin. The Condor, 93(3), 503-515. https://doi.org/10.2307/1368182

Bernasco, W. (2006). Co-offending and the choice of target areas in burglary. Journal of Investigative Psychology and Offender Profiling, 3(3), 139-155.

Bernasco, W. (2008). Them Again? Same Offender Involvement in Repeat and Near Repeat Burglaries. European Journal of Criminology, 5(4), 411-431.

Bernasco, W. (2009). Foraging Strategies of Homo Criminalis: Lessons from Behavioral Ecology. Crime Patterns and Analysis, 2(1), 5-16. http://www.eccajournal.org/V2N1S2009/Bernasco.pdf

Bernasco, W. (2010). Modeling Micro-Level Crime Location Choice: Application of the Discrete Choice Framework to Crime at Places. Journal of Quantitative Criminology, 26(1), 113-138. https://doi.org/10.1007/s10940-009-9086-6

Bernasco, W., Johnson, S. D., \& Ruiter, S. (2015). Learning where to offend: Effects of past on future burglary locations. Applied Geography, 60, 120-129.

Bernasco, W., Lammers, M., \& van der Beek, K. (2016). Cross-border crime patterns unveiled by exchange of DNA profiles in the European Union [journal article]. Security journal, 29(4), 640660. https://doi.org/10.1057/sj.2015.27

Bernasco, W., \& Nieuwbeerta, P. (2005). How Do Residential Burglars Select Target Areas? A New Approach to the Analysis of Criminal Location Choice. British Journal of Criminology, 45(3), 296-315. https://doi.org/10.1093/bjc/azh070

Binmore, K. G. O. S. e. (2012). Evolution and rationality : decisions, co-operation and strategic behaviour. Cambridge : Cambridge University Press. http://lib.ugent.be/catalog/rug01:001886530

Bolnick, D. I., Svanbäck, R., Fordyce, J. A., Yang, L. H., Davis, J. M., Hulsey, C. D., \& Forister, M. L. (2003). The ecology of individuals: incidence and implications of individual specialization. The American Naturalist, 161(1), 1-28.

Braithwaite, A., \& Johnson, S. D. (2015). The battle for Baghdad: Testing hypotheses about insurgency from risk heterogeneity, repeat victimization, and denial policing approaches. Terrorism and Political Violence, 27(1), 112-132.

Brantingham, P. J. (2013). Prey selection among Los Angeles car thieves. Crime Science, 2(3), 1-11.

Brantingham, P. J., \& Brantingham, P. L. (1993). Environment, routine and situation: Toward a pattern theory of crime. Advances in criminological theory, 5(2), 259-294.

Brantingham, P. J., \& Brantingham, P. L. (2008). Crime Pattern Theory. In R. Wortley \& L. Mazerolle (Eds.), Environmental Criminology and Crime Analysis (pp. 78-93). Willan. 
Brantingham, P. J., Brantingham, P. L., \& Andresen, M. A. (2016). The geometry of crime and crime pattern theory. In R. Wortley \& M. Townsley (Eds.), Environmental Criminology and Crime Analysis: Situating the Theory, Analytic Approach and Application (Vol. 2, pp. 98-115). Routledge. https://doi.org/10.4324/9781315709826

Brantingham, P. J., \& Tita, G. (2008). Offender mobility and crime pattern formation from first principles. Artificial crime analysis systems: using computer simulations and geographic information systems, 193-208.

Brosnan, S. F. (2013). Justice- and fairness-related behaviors in nonhuman primates. Proceedings of the National Academy of Sciences, 110(Supplement 2), 10416-10423. https://doi.org/10.1073/pnas.1301194110

Burgason, K., \& Walker, J. (2013). Optimal Foraging Theory's Application to Internet Sex Offender Search Behavior: A Theoretical Model for Computer Forensic Investigations. J Forensic Investigation, 1(1), 6.

Burkart, J. M., Brügger, R. K., \& van Schaik, C. P. (2018). Evolutionary Origins of Morality: Insights From Non-human Primates [Review]. Frontiers in Sociology, 3(17). https://doi.org/10.3389/fsoc.2018.00017

Cantor, M., Pires, M. M., Longo, G. O., Guimarães, P. R., \& Setz, E. Z. F. (2013). Individual variation in resource use by opossums leading to nested fruit consumption. Oikos, 122(7), 1085-1093.

Chainey, S. P., Curtis-Ham, S. J., Evans, R. M., \& Burns, G. J. (2018). Examining the extent to which repeat and near repeat patterns can prevent crime. Policing: An International Journal, 41(5), 608-622.

Chainey, S. P., \& da Silva, B. F. A. (2016). Examining the extent of repeat and near repeat victimisation of domestic burglaries in Belo Horizonte, Brazil. Crime Science, 5(1), 1. https://doi.org/10.1186/s40163-016-0049-6

Chainey, S. P., \& Silva, B. F. A. (2016). Examining the extent of repeat and near repeat victimisation of domestic burglaries in Belo Horizonte, Brazil. Crime Science, 5(1), 1-10.

Charnov, E. L. (1976a). Optimal foraging, the marginal value theorem. Theoretical Population Biology, 9(2), 129-136. https://doi.org/https://doi.org/10.1016/0040-5809(76)90040-X

Charnov, E. L. (1976b). Optimal Foraging: Attack Strategy of a Mantid. The American Naturalist, 110(971), 141-151. http://www.jstor.org/stable/2459883

Cornish, D. B., \& Clarke, R. V. (1986). The reasoning criminal : rational choice perspectives on offending. New York (N.Y.) : Springer. http://lib.ugent.be/catalog/rug01:000119787

Dabney, D. A., Hollinger, R. C., \& Dugan, L. (2004). Who actually steals? A study of covertly observed shoplifters. Justice Quarterly, 21(4), 693-728. https://doi.org/10.1080/07418820400095961

Davies, N. B., Krebs, J. R., \& West, S. A. (2012). An Introduction to Behavioural Ecology (4th ed.). Wiley Blackwell.

De Moor, S., Vandeviver, C., \& Vander Beken, T. (2018). Integrating police-recorded crime data and DNA data to study serial co-offending behaviour. European Journal of Criminology, 1477370817749499.

Fagan, J., \& Freeman, R. B. (1999). Crime and work. Crime and Justice, 25, 225-290.

Felson, M. (2006). Crime and nature. Sage.

Frith, M. J., Johnson, S. D., \& Fry, H. M. (2017). Role of the Street Network in Burglars' Spatial Decision-Making Criminology, 55(2), 344-376.

Funk, D. J. (2019). Specialization. In J. C. Choe (Ed.), Encyclopedia of Animal Behavior (Second Edition) (pp. 101-107). Academic Press. https://doi.org/https://doi.org/10.1016/B978-0-12-8096338.20867-4

Gerstner, D. (2018). Using Predictive Policing to Prevent Residential Burglary: Findings from the Pilot Project P4 in Baden-Württemberg, Germany. European Law Enforcement Research BulletinSpecial Conference Edition Nr. 4,

Giraldeau, L.-A., \& Caraco, T. (2000). Social Foraging Theory. Princeton University Press. https://doi.org/10.2307/j.ctv36zrk6 
Giraldeau, L.-A., \& Pyke, G. H. (2019). Group Foraging. In J. C. Choe (Ed.), Encyclopedia of Animal Behavior (Second Edition) (pp. 191-200). Academic Press.

https://doi.org/https://doi.org/10.1016/B978-0-12-809633-8.20868-6

Glasner, P., Johnson, S. D., \& Leitner, M. (2018). A comparative analysis to forecast apartment burglaries in Vienna, Austria, based on repeat and near repeat victimization. Crime Science, $7(1), 9$.

Goodwill, A. M. (2014). Where to next? Importance of directional considerations in offender geospatial sequential decision making. Legal and Criminological Psychology, 19(2), 218-220.

Grant, M. J., \& Booth, A. (2009). A typology of reviews: an analysis of 14 review types and associated methodologies. Health Information \& Libraries Journal, 26(2), 91-108. https://doi.org/https://doi.org/10.1111/j.1471-1842.2009.00848.x

Hager, S. B. (2010). The Diversity of Behavior. Nature Education Knowledge, 4(2), 66.

Halevi, G., Moed, H., \& Bar-llan, J. (2017). Suitability of Google Scholar as a source of scientific information and as a source of data for scientific evaluation-Review of the literature. Journal of Informetrics, 11(3), 823-834.

Hering, A. S., \& Bair, S. (2014). Characterizing spatial and chronological target selection of serial offenders. Journal of the Royal Statistical Society: Series C (Applied Statistics), 63(1), 123-140.

Humphries, N. E., Queiroz, N., Dyer, J. R., Pade, N. G., Musyl, M. K., Schaefer, K. M., Fuller, D. W., Brunnschweiler, J. M., Doyle, T. K., \& Houghton, J. D. (2010). Environmental context explains Lévy and Brownian movement patterns of marine predators. Nature, 465(7301), 1066-1069.

Johnson, S. D. (2014). How do offenders choose where to offend? Perspectives from animal foraging. Legal and Criminological Psychology, 19(2), 193-210. https://doi.org/10.1111/lcrp.12061

Johnson, S. D., \& Bowers, K. J. (2004a). The burglary as clue to the future: The beginnings of prospective hot-spotting. European Journal of Criminology, 1(2), 237-255.

Johnson, S. D., \& Bowers, K. J. (2004b). The stability of space-time clusters of burglary. British Journal of Criminology, 44(1), 55-65.

Johnson, S. D., Bowers, K. J., Birks, D. J., \& Pease, K. (2009). Predictive mapping of crime by ProMap: accuracy, units of analysis, and the environmental backcloth. In Putting crime in its place (pp. 171-198). Springer.

Johnson, S. D., \& Summers, L. (2015). Testing ecological theories of offender spatial decision making using a discrete choice model. Crime \& Delinquency, 61(3), 454-480.

Johnson, S. D., Summers, L., \& Pease, K. (2009). Offender as Forager? A Direct Test of the Boost Account of Victimization. Journal of Quantitative Criminology, 25(2), 181-200. http://dx.doi.org/10.1007/s10940-008-9060-8

Kacelnik, A. (2006). Meanings of rationality. In S. Hurley \& M. Nudds (Eds.), Rational Animals? Oxford University Press.

Knox, E. G. (1964). The Detection of Space-Time Interactions. Journal of the Royal Statistical Society: Series C (Applied Statistics), 13(1), 25-29. https://doi.org/10.2307/2985220

Krebs, J. R., Ryan, J. C., \& Charnov, E. L. (1974). Hunting by expectation or optimal foraging? A study of patch use by chickadees. Animal Behaviour, 22, 953-IN953.

Lammers, M. (2014). Are Arrested and Non-Arrested Serial Offenders Different? A Test of Spatial Offending Patterns Using DNA Found at Crime Scenes. Journal of Research in Crime and Delinquency, 51(2), 143-167. https://doi.org/10.1177/0022427813504097

Lammers, M., \& Bernasco, W. (2013). Are mobile offenders less likely to be caught? The influence of the geographical dispersion of serial offenders' crime locations on their probability of arrest. European Journal of Criminology, 10(2), 168-186. https://doi.org/10.1177/1477370812464533

Li, G., Haining, R., Richardson, S., \& Best, N. (2014). Space-time variability in burglary risk: a Bayesian spatio-temporal modelling approach. Spatial Statistics, 9, 180-191.

Lindegaard, M. R., Liebst, L. S., Bernasco, W., Heinskou, M. B., Philpot, R., Levine, M., \& Verbeek, P. (2017). Consolation in the aftermath of robberies resembles post-aggression consolation in chimpanzees. PLoS One, 12(5), e0177725. https://doi.org/10.1371/journal.pone.0177725 
MacArthur, R. H., \& Pianka, E. R. (1966). On optimal use of a patchy environment. The American Naturalist, 100(916), 603-609.

Malleson, N. (2012). Using agent-based models to simulate crime. In Agent-based models of geographical systems (pp. 411-434). Springer.

Malleson, N., Heppenstall, A., See, L., \& Evans, A. (2013). Using an agent-based crime simulation to predict the effects of urban regeneration on individual household burglary risk. Environment and Planning B: Planning and Design, 40(3), 405-426.

Malleson, N., See, L., Evans, A., \& Heppenstall, A. (2012). Implementing comprehensive offender behaviour in a realistic agent-based model of burglary. Simulation, 88(1), 50-71.

Marchione, E., \& Johnson, S. D. (2013). Spatial, temporal and spatio-temporal patterns of maritime piracy. Journal of Research in Crime and Delinquency, 50(4), 504-524.

Marshall, H. H., Carter, A. J., Ashford, A., Rowcliffe, J. M., \& Cowlishaw, G. (2013). How do foragers decide when to leave a patch? A test of alternative models under natural and experimental conditions. Journal of Animal Ecology, 82(4), 894-902. https://doi.org/doi:10.1111/13652656.12089

Martín-Martín, A., Orduna-Malea, E., Thelwall, M., \& López-Cózar, E. D. (2018). Google Scholar, Web of Science, and Scopus: A systematic comparison of citations in 252 subject categories. Journal of Informetrics, 12(4), 1160-1177.

Medel, M., Lu, Y., \& Chow, E. (2015). Mexico's drug networks: Modeling the smuggling routes towards the United States. Applied geography, 60, 240-247.

Morselli, C., \& Royer, M.-N. (2008). Criminal mobility and criminal achievement. Journal of Research in Crime and Delinquency, 45(1), 4-21. http://jrc.sagepub.com/cgi/reprint/45/1/4

Muller, M. N., \& Wrangham, R. W. (Eds.). (2009). Sexual Coercion in Primates and Humans. Harvard University Press. http://www.jstor.org/stable/j.ctt13x0j2b.

Nobles, M. R., Ward, J. T., \& Tillyer, R. (2016). The impact of neighborhood context on spatiotemporal patterns of burglary. Journal of Research in Crime and Delinquency, 53(5), 711-740.

Nonacs, P. (2019). Patch Exploitation. In J. C. Choe (Ed.), Encyclopedia of Animal Behavior (Second Edition) (pp. 139-148). Academic Press. https://doi.org/https://doi.org/10.1016/B978-0-12809633-8.20821-2

Orians, G. H., \& Pearson, N. E. (1979). On the Theory of Central Place Foraging. In D. J. Horn, R. D. Mitchell, \& G. R. Stairs (Eds.), Analysis of Ecological Systems (pp. 154-177). Ohio State University Press.

Parker, G. A., \& Smith, J. M. (1990). Optimality theory in evolutionary biology. Nature, 348, 27. https://doi.org/10.1038/348027a0

Pease, K. (2014). Voles don't take taxis. Legal and Criminological Psychology, 19(2), 221-223. https://doi.org/doi:10.1111/lcrp.12056

Pires, S. F., \& Clarke, R. V. (2011). Sequential foraging, itinerant fences and parrot poaching in Bolivia. The British Journal of Criminology, 51(2), 314-335.

Pirolli, P., \& Card, S. (1999). Information foraging. Psychological review, 106(4), 643.

Pitcher, A. B., \& Johnson, S. D. (2011). Exploring theories of victimization using a mathematical model of burglary. Journal of Research in Crime and Delinquency, 48(1), 83-109.

Porter, M. D., \& Reich, B. J. (2012). Evaluating temporally weighted kernel density methods for predicting the next event location in a series. Annals of GIS, 18(3), 225-240.

Pyke, G. H. (2019a). Animal Movements - An Optimal Foraging Theory Approach. In J. C. Choe (Ed.), Encyclopedia of Animal Behavior (Second Edition) (pp. 149-156). Academic Press. https://doi.org/https://doi.org/10.1016/B978-0-12-809633-8.90160-2

Pyke, G. H. (2019b). Optimal Foraging Theory: An Introduction. In J. C. Choe (Ed.), Encyclopedia of Animal Behavior (Second Edition) (pp. 111-117). Academic Press. https://doi.org/https://doi.org/10.1016/B978-0-12-809633-8.01156-0

Pyke, G. H., \& Stephens, D. W. (2019). Optimal Foraging Theory: Application and Inspiration in Human Endeavors Outside Biology. In J. C. Choe (Ed.), Encyclopedia of Animal Behavior 
(Second Edition) (pp. 217-222). Academic Press.

https://doi.org/https://doi.org/10.1016/B978-0-12-809633-8.90161-4

Rajala, A. K., \& Hantula, D. A. (2000). Towards a behavioral ecology of consumption: delay-reduction effects on foraging in a simulated Internet mall. Managerial and Decision Economics, 21(3-4), 145-158.

Ratcliffe, J. H. (2009). Near Repeat Calculator. In

Rey, S. J., Mack, E. A., \& Koschinsky, J. (2012). Exploratory space-time analysis of burglary patterns. Journal of Quantitative Criminology, 28(3), 509-531.

Rosser, G., Davies, T., Bowers, K. J., Johnson, S. D., \& Cheng, T. (2017). Predictive crime mapping: arbitrary grids or street networks? Journal of Quantitative Criminology, 33(3), 569-594.

Roughgarden, J. (1972). Evolution of Niche Width. The American Naturalist, 106(952), 683-718. http://www.jstor.org/stable/2459501

Schulz, A. W. (2014). Niche construction, adaptive preferences, and the differences between fitness and utility. Biology \& Philosophy, 29(3), 315-335.

Sherman, L. W. (1990). Police crackdowns: Initial and residual deterrence. Crime and Justice, 12, 1-48.

Sidebottom, A. (2012). Repeat burglary victimization in Malawi and the influence of housing type and area-level affluence. Security journal, 25(3), 265-281.

Sih, A., \& Christensen, B. (2001). Optimal diet theory: when does it work, and when and why does it fail? Animal Behaviour, 61(2), 379-390. https://doi.org/10.1006/anbe.2000.1592

Simpson, E. H. (1949). Measurement of Diversity. Nature, 163(4148), 688-688. https://doi.org/10.1038/163688a0

Smith, A. P., Bailey, A. R., Chow, J. J., Beckmann, J. S., \& Zentall, T. R. (2016). Suboptimal Choice in Pigeons: Stimulus Value Predicts Choice over Frequencies. PLoS One, 11(7), e0159336. https://doi.org/10.1371/journal.pone.0159336

Song, C., Koren, T., Wang, P., \& Barabási, A.-L. (2010). Modelling the scaling properties of human mobility. Nature Physics, 6(10), 818-823. https://doi.org/10.1038/nphys1760

Sorg, E. T., Wood, J. D., Groff, E. R., \& Ratcliffe, J. H. (2017). Explaining dosage diffusion during hot spot patrols: An application of optimal foraging theory to police officer behavior. Justice Quarterly, 34(6), 1044-1068.

Stephens, D. W. (2008). Decision ecology: Foraging and the ecology of animal decision making [journal article]. Cognitive, Affective, \& Behavioral Neuroscience, 8(4), 475-484. https://doi.org/10.3758/cabn.8.4.475

Stephens, D. W., Brown, J. S., \& Ydenberg, R. C. (2007). Foraging: behavior and ecology. University of Chicago Press.

Stephens, D. W., \& Krebs, J. R. (1986). Foraging theory. Princeton University Press.

Summers, L., Johnson, S. D., \& Rengert, G. F. (2010). The use of maps in offender interviewing. In W. Bernasco (Ed.), Offenders on Offending. Learning about crime from criminals (pp. 246-272). Willan.

Tinker, M. T., Guimarães, P. R., Novak, M., Marquitti, F. M. D., Bodkin, J. L., Staedler, M., Bentall, G., \& Estes, J. A. (2012). Structure and mechanism of diet specialisation: testing models of individual variation in resource use with sea otters. Ecology Letters, 15(5), 475-483.

Tobler, W. R. (1970). A computer movie simulating urban growth in the Detroit region. Economic geography, 46(sup1), 234-240.

Townsley, M., Birks, D., Ruiter, S., Bernasco, W., \& White, G. (2016). Target Selection Models with Preference Variation Between Offenders. Journal of Quantitative Criminology, 32(2), 283304. https://doi.org/10.1007/s10940-015-9264-7

Townsley, M., \& Oliveira, A. (2015). Space-time dynamics of maritime piracy [journal article]. Security Journal, 28(3), 217-229. https://doi.org/10.1057/sj.2012.45

Townsley, M., \& Sidebottom, A. (2010). All offenders are equal, but some are more equal than others: variation in journeys to crime between offenders. Criminology, 48(3), 897-917. <Go to $|S|>: / / W O S: 000280972900009$ 
Van Daele, S. (2010). Mobility and distance decay at the aggregated and individual level. Safety, societal problems and citizens' perceptions: New empirical data, theories and analyses, 41-59.

van Gelder, J.-L., \& Van Daele, S. (2014). Innovative data collection methods in criminological research: editorial introduction [journal article]. Crime Science, 3(1), 6. https://doi.org/10.1186/s40163-014-0006-1

Vandeviver, C., \& Bernasco, W. (2019). "Location, Location, Location”: Effects of Neighborhood and House Attributes on Burglars' Target Selection. Journal of Quantitative Criminology. https://doi.org/10.1007/s10940-019-09431-y

Vasconcelos, M., Monteiro, T., \& Kacelnik, A. (2015). Irrational choice and the value of information [Article]. Scientific Reports, 5, 13874. https://doi.org/10.1038/srep13874

Verdolin, J. L. (2006). Meta-Analysis of Foraging and Predation Risk Trade-Offs in Terrestrial Systems. Behavioral Ecology and Sociobiology, 60(4), 457-464. http://www.jstor.org/stable/25063837

Waite, T. A., \& Field, K. L. (2007). Foraging with Others: Games Social Foragers Play. In D. W. Stephens, J. S. Brown, \& R. C. Ydenberg (Eds.), Foraging: Behavior and Ecology (pp. 331-364). The University of Chicago Press.

Wang, Z., \& Liu, X. (2017). Analysis of Burglary Hot Spots and Near-Repeat Victimization in a Large Chinese City. ISPRS International Journal of Geo-Information, 6(5), 148.

Watanabe, Y. Y., Ito, M., \& Takahashi, A. (2014). Testing optimal foraging theory in a penguin-krill system. Proceedings of the Royal Society of London B: Biological Sciences, 281(1779), 20132376.

Weisburd, D. L. (2015). The Law of Crime Concentration and the Criminology of Place. Criminology, 53(2), 133-157. https://doi.org/10.1111/1745-9125.12070

Westneat, D., \& Fox, C. W. (2010). Evolutionary behavioral ecology. Oxford University Press.

Wheeler, A. (2012). The Moving Home Effect: A Quasi Experiment Assessing Effect of Home Location on the Offence Location. Journal of Quantitative Criminology, 28(4), 587-606. https://doi.org/10.1007/s10940-011-9161-7

Ydenberg, R. C., Brown, J. S., \& Stephens, D. W. (2007). Foraging: an overview. In D. W. Stephens, J. S. Brown, \& R. C. Ydenberg (Eds.), Foraging: Behavior and ecology (pp. 1-28). The University of Chicago Press.

Youstin, T. J., Nobles, M. R., Ward, J. T., \& Cook, C. L. (2011). Assessing the generalizability of the near repeat phenomenon. Criminal Justice and Behavior, 38(10), 1042-1063.

Yu, S.-s. V., \& Maxfield, M. G. (2013). Ordinary business: Impacts on commercial and residential burglary. British Journal of Criminology, 54(2), 298-320.

Zach, R., \& Falls, J. B. (1976). Do ovenbirds (Aves: Parulidae) hunt by expectation? Canadian Journal of Zoology, 54(11), 1894-1903. 
Table 1: Definitions, decisions, currency, and constraints underlying the marginal value hypothesis.

\begin{tabular}{|c|c|c|}
\hline & (e.g., squirrels $\frac{\text { Animals }}{\text { foraging for beechnuts) }}$ & (e.g., burglars foraging for valuable items) \\
\hline Definitions & $\begin{array}{l}\text { - A patch is a discrete location where an animal can harvest energy (e.g., } \\
\text { a beech tree where a squirrel can find beechnuts). Energy cannot be } \\
\text { harvested outside patches } \\
\text { - A habitat is an area where the animal lives. It includes multiple patches. }\end{array}$ & $\begin{array}{l}\text { - A residential neighbourhood is a discrete location where an offender } \\
\text { can obtain valuable items by committing residential burglaries. } \\
\text { Burglaries can only be committed in residential neighbourhoods. } \\
\text { - A city is an area where the offender lives. It includes multiple } \\
\text { residential neighbourhoods. }\end{array}$ \\
\hline Decision & $\begin{array}{l}\text { - How long }(t) \text { to stay in a patch while foraging, i.e. when to leave, with } \\
\text { feasible choices } 0 \leq t_{i}<\infty \text {. E.g., how long will a squirrel harvest } \\
\text { beechnuts from the same tree? }\end{array}$ & $\begin{array}{l}\text { - How long }(t) \text { to continue committing burglaries in the same } \\
\text { neighbourhood, with feasible choices } 0 \leq t_{i}<\infty \text {. E.g., when to start } \\
\text { targeting another neighbourhood? }\end{array}$ \\
\hline Currency & $\begin{array}{l}\text { - The long-term average energy intake; i.e. nutritional value, in calories } \\
\text { per month. }\end{array}$ & $\begin{array}{l}\text { - The long-term average benefit of committing burglaries; i.e. value of } \\
\text { stolen items, in euros per month. }\end{array}$ \\
\hline Constraints & $\begin{array}{l}\text { - Foraging in and searching for a patch are mutually exclusive activities: } \\
\text { a squirrel cannot eat when searching for the next beechnut tree. } \\
\text { - Searching for a patch does not induce search costs. } \\
\text { - Patches are encountered sequentially and the patch-encounter rate } \\
\text { follows a Poisson process. } \\
\text { - Patch-encounter rates are independent of the length }(t) \text { of stay in a } \\
\text { patch. } \\
\text { - The expected calory-intake per time unit (e.g., per month) is a well- } \\
\text { defined gain function } g(t) \text { of time in the patch, with the following } \\
\text { characteristics: } \\
\text { Gain }(\text { calory-intake) is zero if the patch is left upon encounter: } \\
(g(0)=0) \text {. }\end{array}$ & $\begin{array}{l}\text { - Committing burglaries and searching for a new target neighbourhood } \\
\text { are mutually exclusive activities: a burglar cannot commit burglaries } \\
\text { while searching for a new target neighbourhood. } \\
\text { - Searching for a new target neighbourhood does not involve search } \\
\text { costs. } \\
\text { - Target neighbourhoods are encountered sequentially and the } \\
\text { neighbourhood-encounter rate follows a Poisson process. } \\
\text { - Neighbourhood-encounter rates are independent of the length }(t) \text { of } \\
\text { how long the burglar has been committing burglaries in the same } \\
\text { neighbourhood } \\
\text { - The expected value of stolen items per time unit (e.g., per month) is a } \\
\text { well-defined gain function } g(t) \text { of the time the burglar has been } \\
\text { committing burglaries in the neighbourhood, with the following } \\
\text { characteristics: } \\
\text { o Gain (value of items stolen) is zero if the neighbourhood is left } \\
\text { upon encounter: }(g(0)=0) \text {; i.e., if the burglar judges the } \\
\text { neighbourhood as unsuitable upon first inspection. }\end{array}$ \\
\hline
\end{tabular}




\begin{tabular}{|c|c|c|}
\hline & $\begin{array}{l}\text { The function may initially increase }\left(g^{\prime}(t)>0\right) \text { but eventually } \\
\text { becomes negatively accelerated }\left(g^{\prime \prime}(t)<0, \forall t \geq t^{\prime}\right), \\
\text { reflecting resource depletion. } \\
\circ \text { Encounters with new patches are the result of random search. } \\
\text { - All patches in the habitat are characterized by the same gain function } \\
\text { (e.g., all beech trees provide the same number of beechnuts). }\end{array}$ & $\begin{array}{l}\text { The function may initially increase }\left(g^{\prime}(t)>0\right) \text { but eventually } \\
\text { becomes negatively accelerated }\left(g^{\prime \prime}(t)<0, \forall t \geq t^{y}\right) \text {, } \\
\text { reflecting resource depletion; e.g., decreasing opportunity due to } \\
\text { increasing vigilance and prevention measures installed by } \\
\text { neighbourhood residents. } \\
\text { Encounters with new neighbourhoods are the result of random } \\
\text { search; i.e., burglars encounter new target neighbourhoods by } \\
\text { coincidence rather than by plan. } \\
\text { - All neighbourhoods in the city are characterized by the same gain } \\
\text { function (e.g., the neighbourhoods contain equal numbers of residential } \\
\text { properties and do not differ in suitability for burglary). }\end{array}$ \\
\hline $\begin{array}{l}\text { Marginal } \\
\text { value } \\
\text { hypothesis }\end{array}$ & $\begin{array}{l}\text { A foraging organism will stay in a patch until the marginal gain rate in the } \\
\text { patch has dropped to the average gain rate of the patches in its habitat. }\end{array}$ & $\begin{array}{l}\text { A residential burglar will continue committing burglaries in the same } \\
\text { neighbourhood until the marginal gain rate in the neighbourhood has } \\
\text { dropped to the average gain rate of the neighbourhoods in the city. }\end{array}$ \\
\hline
\end{tabular}


Table 2: Overview of the included studies' purpose and main characteristics.

\begin{tabular}{|c|c|c|c|c|c|c|c|}
\hline$\#$ & Study & $\begin{array}{l}\text { Geographic } \\
\text { region }\end{array}$ & $\begin{array}{l}\text { Period of } \\
\text { used data }\end{array}$ & Studied crime types & Analytic strategy & Purpose & Findings \\
\hline 1 & Badiora, 2017 & Nigeria & $2009-2013$ & Motor vehicle theft & Correlational analysis & Target choice & $\begin{array}{l}\text { There is a positive relationship between target } \\
\text { abundance and theft rates, yet abundance in itself } \\
\text { is insufficient to explain differences in theft rates. }\end{array}$ \\
\hline 2 & $\begin{array}{l}\text { Bernasco \& } \\
\text { Nieuwbeerta, } \\
2004\end{array}$ & $\begin{array}{l}\text { The } \\
\text { Netherlands }\end{array}$ & $1996-2001$ & Residential burglary & choice & Location choice & $\begin{array}{l}\text { The likelihood of a neighbourhood being } \\
\text { selected for burglary is positively influenced by } \\
\text { the neighbourhood's lack of guardianship, } \\
\text { physical accessibility and the number of potential } \\
\text { objects in the area. }\end{array}$ \\
\hline 3 & $\begin{array}{l}\text { Bernasco, } \\
2006\end{array}$ & $\begin{array}{l}\text { The } \\
\text { Netherlands }\end{array}$ & $1996-2004$ & Residential burglary & $\begin{array}{l}\text { Discrete } \\
\text { analysis }\end{array}$ & Location choice & $\begin{array}{l}\text { Both solitary burglars and burglar groups prefer } \\
\text { physically accessible areas that are close to the } \\
\text { offenders' homes. }\end{array}$ \\
\hline 4 & $\begin{array}{l}\text { Bernasco, } \\
2010\end{array}$ & $\begin{array}{l}\text { The } \\
\text { Netherlands }\end{array}$ & $2002-2007$ & Residential burglary & $\begin{array}{l}\text { Discrete } \\
\text { analysis }\end{array}$ & Location choice & $\begin{array}{l}\text { The likelihood of an area being selected for } \\
\text { burglary is positively influenced by the number } \\
\text { of properties and their average value, the } \\
\text { percentage } 15-25 \text { years old in the population and } \\
\text { the area's proximity. }\end{array}$ \\
\hline 5 & $\begin{array}{l}\text { Bernasco, } \\
\text { Johnson \& } \\
\text { Ruiter, } 2015\end{array}$ & UK & $2007-2012$ & Residential burglary & $\begin{array}{l}\text { Discrete choice } \\
\text { analysis }\end{array}$ & $\begin{array}{l}\text { Spatiotemporal clustering } \\
\text { of crime and crime- } \\
\text { control: Repeat and near- } \\
\text { repeat victimisation }\end{array}$ & $\begin{array}{l}\text { Burglars were more likely to commit a burglary } \\
\text { in previously targeted areas, as well as areas that } \\
\text { are nearby, especially if the prior burglary was } \\
\text { recent. }\end{array}$ \\
\hline 6 & $\begin{array}{l}\text { Braithwaite \& } \\
\text { Johnson, } 2015\end{array}$ & Iraq & 2005 & Insurgent violence & Regression analysis & $\begin{array}{l}\text { Spatiotemporal clustering } \\
\text { of crime and crime- } \\
\text { control: Repeat and near- } \\
\text { repeat victimisation }\end{array}$ & $\begin{array}{l}\text { The location of insurgency is mostly the result of } \\
\text { time-invariant risk heterogeneity, and, to a lesser } \\
\text { extent, prior victimisation. }\end{array}$ \\
\hline 7 & $\begin{array}{l}\text { Brantingham, } \\
2013\end{array}$ & USA & $\begin{array}{l}2003-2004 \\
2004-2005\end{array}$ & Motor vehicle theft & Correlational analysis & Target choice & $\begin{array}{l}\text { Theft rates are mainly the result of differences in } \\
\text { target abundance in the environment. }\end{array}$ \\
\hline 8 & $\begin{array}{l}\text { Chainey \& } \\
\text { Braulio, } 2016\end{array}$ & Brazil & $2012-2014$ & Residential burglary & $\begin{array}{l}\text { Near } \\
\text { calculation }\end{array}$ & $\begin{array}{l}\text { Spatiotemporal clustering } \\
\text { of crime and crime- }\end{array}$ & $\begin{array}{l}\text { The risk of victimisation is elevated following a } \\
\text { prior burglary, though the levels of repeat and }\end{array}$ \\
\hline
\end{tabular}




\begin{tabular}{|c|c|c|c|c|c|c|c|}
\hline & & & & & & $\begin{array}{l}\text { control: Repeat and near- } \\
\text { repeat victimisation }\end{array}$ & $\begin{array}{l}\text { near-repeat victimisation is much lower } \\
\text { compared to those found in Western studies. }\end{array}$ \\
\hline 9 & $\begin{array}{l}\text { Chainey et al., } \\
2018\end{array}$ & New Zealand & $2013-2014$ & Residential burglary & $\begin{array}{l}\text { Near repeat } \\
\text { calculation, kernel } \\
\text { density estimation for } \\
\text { hot-spots }\end{array}$ & $\begin{array}{l}\text { Spatiotemporal clustering } \\
\text { of crime and crime- } \\
\text { control: Repeat and near- } \\
\text { repeat victimisation }\end{array}$ & $\begin{array}{l}\text { There is a demonstrated pattern of (near-)repeat } \\
\text { victimisation, though the extent of these patterns } \\
\text { varies across the four study regions. }\end{array}$ \\
\hline 10 & Gerstner, 2018 & Germany & $2015-2016$ & Residential burglary & $\begin{array}{lr}\text { Predictive } & \text { crime } \\
\text { mapping, regression } \\
\text { analysis }\end{array}$ & $\begin{array}{l}\text { Spatiotemporal clustering } \\
\text { of crime and crime- } \\
\text { control: Repeat and near- } \\
\text { repeat victimisation }\end{array}$ & $\begin{array}{l}\text { Place-based predictive policing strategies have a } \\
\text { moderate effect on burglary reduction. The } \\
\text { acceptance of predictive policing within the } \\
\text { police force varies. }\end{array}$ \\
\hline 11 & $\begin{array}{l}\text { Glasner et al., } \\
2018\end{array}$ & Austria & 2013-2016 & Residential burglary & $\begin{array}{l}\text { Near repeat } \\
\text { calculation, predictive } \\
\text { crime mapping }\end{array}$ & $\begin{array}{l}\text { Spatiotemporal clustering } \\
\text { of crime and crime- } \\
\text { control: Repeat and near- } \\
\text { repeat victimisation }\end{array}$ & $\begin{array}{l}\text { The pattern of residential burglary is influenced } \\
\text { by repeat and near-repeat victimisation. Out of } \\
\text { two proposed predictive methods that identify } \\
\text { future burglary locations, a strategy that uses } \\
\text { information on sequences of burglaries is more } \\
\text { efficient. }\end{array}$ \\
\hline 12 & $\begin{array}{l}\text { Hering \& Bair, } \\
2014\end{array}$ & USA & $2010-2011$ & $\begin{array}{l}\text { Residential and } \\
\text { commercial burglary, } \\
\text { arson, robbery, theft } \\
\text { from motor vehicle }\end{array}$ & $\begin{array}{ll}\text { Spatial and } & \text { spatio- } \\
\text { temporal } & \text { cluster } \\
\text { analysis } & \end{array}$ & $\begin{array}{l}\text { Spatiotemporal clustering } \\
\text { of crime and crime- } \\
\text { control: Repeat and near- } \\
\text { repeat victimisation }\end{array}$ & $\begin{array}{l}\text { Robbers' activity becomes more clustered as } \\
\text { time progresses instead of becoming more } \\
\text { dispersed, inconsistent with OFT predictions. } \\
\text { Burglary is mostly clustered, though some } \\
\text { burglars avoid clustering by spacing their crimes. }\end{array}$ \\
\hline 13 & $\begin{array}{l}\text { Johnson } \& \\
\text { Bowers, 2004a }\end{array}$ & UK & $1999-2000$ & Residential burglary & Knox test & $\begin{array}{l}\text { Spatiotemporal clustering } \\
\text { of crime and crime- } \\
\text { control: Repeat and near- } \\
\text { repeat victimisation }\end{array}$ & $\begin{array}{l}\text { A prior residential burglary elevates the } \\
\text { risk of further residential burglaries in the near } \\
\text { future and in close proximity to the victimized } \\
\text { home. }\end{array}$ \\
\hline 14 & $\begin{array}{l}\text { Johnson } \& \\
\text { Bowers, 2004b }\end{array}$ & UK & $1999-2000$ & Residential burglary & $\begin{array}{l}\text { Correlational } \\
\text { analysis, Knox Test }\end{array}$ & $\begin{array}{l}\text { Spatiotemporal clustering } \\
\text { of crime and crime- } \\
\text { control: Repeat and near- } \\
\text { repeat victimisation }\end{array}$ & $\begin{array}{l}\text { Clusters of burglary move as time goes on, } \\
\text { mainly shifting to locations near the original } \\
\text { cluster. }\end{array}$ \\
\hline 15 & Johnson, 2014 & UK & $2007-2012$ & Residential burglary & $\begin{array}{lr}\text { Comparison } & \text { of } \\
\text { probability density }\end{array}$ & $\begin{array}{l}\text { Spatiotemporal clustering } \\
\text { of crime and crime- }\end{array}$ & The distribution of sequential \\
\hline
\end{tabular}




\begin{tabular}{|c|c|c|c|c|c|c|c|}
\hline & & & & & $\begin{array}{lr}\text { function } & \text { with } \\
\text { exponential } & \text { and } \\
\text { power } & \text { law } \\
\text { distributions } & \\
\end{array}$ & $\begin{array}{l}\text { control: Sequential target } \\
\text { selection }\end{array}$ & $\begin{array}{l}\text { inter-event distances is consistent with both } \\
\text { Brownian and Lévy walks. Additionally, } \\
\text { offenders most likely do not unequivocally stick } \\
\text { with one of both strategies. }\end{array}$ \\
\hline 16 & $\begin{array}{l}\text { Johnson, } \\
\text { Bowers, Birks } \\
\text { \& Pease } 2009\end{array}$ & UK & 1996-1997 & Residential burglary & $\begin{array}{l}\text { Predictive crime } \\
\text { mapping }\end{array}$ & $\begin{array}{l}\text { Spatiotemporal clustering } \\
\text { of crime and crime- } \\
\text { control: Repeat and near- } \\
\text { repeat victimisation }\end{array}$ & $\begin{array}{l}\text { An algorithm based on OFT and the literature on } \\
\text { (near-)repeat victimisation predicts the future } \\
\text { locations of crime at a level that exceeds chance } \\
\text { expectation, and also outperforms other hot- } \\
\text { spotting methods. }\end{array}$ \\
\hline 17 & $\begin{array}{l}\text { Johnson, } \\
\text { Summers \& } \\
\text { Pease, } 2009\end{array}$ & UK & $2001-2005$ & $\begin{array}{l}\text { Residential burglary, } \\
\text { theft from motor } \\
\text { vehicle }\end{array}$ & Knox test & $\begin{array}{l}\text { Spatiotemporal clustering } \\
\text { of crime and crime- } \\
\text { control: Repeat and near- } \\
\text { repeat victimisation }\end{array}$ & $\begin{array}{l}\text { Both burglary and theft from motor vehicle } \\
\text { cluster in time and space. Crimes of the same } \\
\text { type occurring closest to each other in space and } \\
\text { time are those most likely to be cleared to the } \\
\text { same offender(s). }\end{array}$ \\
\hline 18 & Li et al., 2014 & UK & $2005-2008$ & Residential burglary & Regression analysis & $\begin{array}{l}\text { Spatiotemporal clustering } \\
\text { of crime and crime- } \\
\text { control: Repeat and near- } \\
\text { repeat victimisation }\end{array}$ & $\begin{array}{l}\text { Areas that are hot spots, cold spots, or neither } \\
\text { differ in terms of whether crime rates increase, } \\
\text { decrease, or remain stable when compared to the } \\
\text { overall rate of victimization. }\end{array}$ \\
\hline 19 & $\begin{array}{l}\text { Medel, Lu \& } \\
\text { Chow, } 2015\end{array}$ & Mexico & $2006-2010$ & Drug trafficking & Network analysis & Location choice & $\begin{array}{l}\text { Drug smuggling routes are selected to maximize } \\
\text { profits and minimize costs and risks. }\end{array}$ \\
\hline 20 & Morselli, 2008 & Canada & NA & $\begin{array}{l}\text { predatory } \\
\text { (i.e., robbery, } \\
\text { burglary, fraud, auto- } \\
\text { theft, and theft) and } \\
\text { market crimes (i.e., } \\
\text { drug dealing, fencing, } \\
\text { smuggling, loan } \\
\text { sharking, sex } \\
\text { peddling, and illegal } \\
\text { gambling operations). }\end{array}$ & Regression analysis & Offender mobility & $\begin{array}{l}\text { Increased mobility is compensated by higher } \\
\text { reported earnings. This relationship is stronger } \\
\text { for predatory crime types than for market crimes. }\end{array}$ \\
\hline
\end{tabular}




\begin{tabular}{|c|c|c|c|c|c|c|c|}
\hline 21 & $\begin{array}{lr}\text { Nobles, Ward } \\
\& \quad \text { Tyllyer, } \\
2016 & \end{array}$ & USA & $2006-2007$ & Residential burglary & Regression analysis & $\begin{array}{l}\text { Spatiotemporal clustering } \\
\text { of crime and crime- } \\
\text { control: Repeat and near- } \\
\text { repeat victimisation }\end{array}$ & $\begin{array}{l}\text { Repeat and near repeat burglary patterns are } \\
\text { conditional on the level and specific dimensions } \\
\text { of neighbourhood disorganisation. }\end{array}$ \\
\hline 22 & $\begin{array}{l}\text { Pires \& } \\
\text { Clarke, } 2011\end{array}$ & Bolivia & $2004-2005$ & $\begin{array}{l}\text { Illegal wildlife } \\
\text { poaching }\end{array}$ & Correlational analysis & Location choice & $\begin{array}{l}\text { The presence of particular parrot species is likely } \\
\text { the result of their environmental abundance, } \\
\text { accessibility to humans and overall enjoyability } \\
\text { as pets, indicating that parrot poachers might be } \\
\text { acting as optimal foragers }\end{array}$ \\
\hline 23 & $\begin{array}{l}\text { Porter \& } \\
\text { Reich, } 2012\end{array}$ & USA & $1999-2011$ & crime & $\begin{array}{l}\text { Kernel density } \\
\text { estimation }\end{array}$ & $\begin{array}{l}\text { Spatiotemporal clustering } \\
\text { of crime and crime- } \\
\text { control: Repeat and near- } \\
\text { repeat victimisation }\end{array}$ & $\begin{array}{l}\text { Future crime events are more likely to occur } \\
\text { close to past events. The effectiveness of } \\
\text { predicting future locations in a crime series } \\
\text { greatly increases when accounting for temporal } \\
\text { variation, showing some support for the foraging } \\
\text { hypothesis. }\end{array}$ \\
\hline 24 & $\begin{array}{l}\text { Rey et al., } \\
2012\end{array}$ & USA & $2005-2009$ & Residential burglary & $\begin{array}{l}\text { Conditional Spatial } \\
\text { Markov Chains }\end{array}$ & $\begin{array}{l}\text { Spatiotemporal clustering } \\
\text { of crime and crime- } \\
\text { control: Repeat and near- } \\
\text { repeat victimisation }\end{array}$ & $\begin{array}{l}\text { Spatial clustering of burglary activity elevates } \\
\text { the risk of further residential burglaries in the } \\
\text { near future and in close proximity to the initial } \\
\text { cluster. }\end{array}$ \\
\hline 25 & $\begin{array}{l}\text { Rosser et al., } \\
2017\end{array}$ & UK & 2013-2014 & Residential burglary & $\begin{array}{l}\text { Predictive crime } \\
\text { mapping }\end{array}$ & $\begin{array}{l}\text { Spatiotemporal clustering } \\
\text { of crime and crime- } \\
\text { control: Repeat and near- } \\
\text { repeat victimisation }\end{array}$ & $\begin{array}{l}\text { A street network-based predictive model largely } \\
\text { outperforms a grid-based alternative in terms of } \\
\text { predictive accuracy. }\end{array}$ \\
\hline 26 & $\begin{array}{l}\text { Sidebottom, } \\
2012\end{array}$ & Malawi & $2004-2005$ & Residential burglary & Correlational analysis & $\begin{array}{l}\text { Spatiotemporal } \\
\text { clustering of crime and } \\
\text { crime-control: Repeat } \\
\text { and near-repeat } \\
\text { victimisation }\end{array}$ & $\begin{array}{l}\text { Seemingly wealthier residences experience } \\
\text { higher rates of repeat victimisation. This pattern } \\
\text { is most pronounced in areas that are, on average, } \\
\text { less affluent. }\end{array}$ \\
\hline 27 & $\begin{array}{l}\text { Sorg et al., } \\
2017\end{array}$ & USA & 2009 & $\begin{array}{l}\text { Police-initiated } \\
\text { activities }\end{array}$ & $\begin{array}{l}\text { Analysis } \\
\text { covariance } \\
\text { (ANCOVA) }\end{array}$ & $\begin{array}{l}\text { Spatiotemporal clustering } \\
\text { of crime and crime- } \\
\text { control: Spatiotemporal }\end{array}$ & $\begin{array}{l}\text { The amount of time spent outside assigned areas } \\
\text { increases as time goes on. Additionally, this } \\
\text { process is hastened in areas that are faced with }\end{array}$ \\
\hline
\end{tabular}




\begin{tabular}{|c|c|c|c|c|c|c|c|}
\hline & & & & & & $\begin{array}{l}\text { variation in hot spot } \\
\text { patrolling }\end{array}$ & $\begin{array}{l}\text { relatively little crime, or in areas that are adjacent } \\
\text { to high-crime areas, a result that is in line with } \\
\text { the qualitative predictions of the patch departure } \\
\text { model. }\end{array}$ \\
\hline 28 & $\begin{array}{l}\text { Townsley \& } \\
\text { Oliveira, } 2015\end{array}$ & $\begin{array}{l}\text { Horn } \\
\text { Africa }\end{array}$ & $2006-2011$ & Maritime piracy & Knox test & $\begin{array}{l}\text { Spatiotemporal clustering } \\
\text { of crime and crime- } \\
\text { control: Repeat and near- } \\
\text { repeat victimisation }\end{array}$ & $\begin{array}{l}\text { Maritime piracy clusters significantly in time and } \\
\text { space. }\end{array}$ \\
\hline 29 & $\begin{array}{l}\text { Wang \& Liu, } \\
2017\end{array}$ & China & 2013 & Residential burglary & Knox test & $\begin{array}{l}\text { Spatiotemporal clustering } \\
\text { of crime and crime- } \\
\text { control: Repeat and near- } \\
\text { repeat victimisation }\end{array}$ & $\begin{array}{l}\text { The risk of burglary varies in time and space. } \\
\text { Clusters of burglary positively impact the risk of } \\
\text { victimisation for nearby areas. }\end{array}$ \\
\hline 30 & Wheeler, 2012 & USA & $2003-2008$ & $\begin{array}{l}\text { assault, burglary, } \\
\text { robbery, } \\
\text { vehicle theft, larceny, } \\
\text { possession } \\
\text { contraband, of } \\
\text { vehicular crime }\end{array}$ & Regression analysis & $\begin{array}{l}\text { Spatiotemporal clustering } \\
\text { of crime and crime- } \\
\text { control: Sequential target } \\
\text { selection }\end{array}$ & $\begin{array}{l}\text { There is a small effect of offenders changing } \\
\text { their residence location on crime location choice. } \\
\text { They tend to commit crimes in locations farther } \\
\text { away from past offences than would be expected } \\
\text { without moving. }\end{array}$ \\
\hline 31 & $\begin{array}{l}\text { Youstin et al., } \\
2011\end{array}$ & USA & $2006-2008$ & $\begin{array}{l}\text { Shootings, motor } \\
\text { vehicle theft and } \\
\text { robberies }\end{array}$ & $\begin{array}{lr}\text { Near } r e p e a t \\
\text { calculation, }\end{array}$ & $\begin{array}{l}\text { Spatiotemporal clustering } \\
\text { of crime and crime- } \\
\text { control: Repeat and near- } \\
\text { repeat victimisation }\end{array}$ & $\begin{array}{l}\text { There is a demonstrable near-repeat pattern for } \\
\text { all studied crime types, though the exact pattern } \\
\text { varies across crime types. }\end{array}$ \\
\hline 32 & $\begin{array}{l}\text { Yu \& } \\
\text { Maxfield, } \\
2013\end{array}$ & USA & $2005-2007$ & $\begin{array}{l}\text { Commercial and } \\
\text { residential burglary }\end{array}$ & Regression analysis & $\begin{array}{l}\text { Spatiotemporal clustering } \\
\text { of crime and crime- } \\
\text { control: Repeat and near- } \\
\text { repeat victimisation }\end{array}$ & $\begin{array}{l}\text { The presence of business premises is linked with } \\
\text { increased victimisation rates, possibly by helping } \\
\text { offenders develop awareness space of the area } \\
\text { where the business is located. }\end{array}$ \\
\hline
\end{tabular}


${ }^{\mathrm{i}}$ It is important to note the distinction between the choice whether or not to engage in illegal activities, or deciding where and when to offend after having made the decision to commit one or more crimes (Cornish \& Clarke, 1986). Environmental criminology mainly concerns itself with the latter decision, which means that Fagan and Freeman's theoretical framework and subsequent applications are not included in this review since its focus lies on the application of OFT in environmental criminology.

${ }^{\text {ii }}$ To illustrate, the combination of foraging and crime resulted in approximately 21,800 hits. 